Volume 1 Nomor 1, November 2020: h. 33 - 46

P-ISSN: 2722-4465, E-ISSN: 2746-8151

Creative Commons Attribution-NonCommercial 4.0 International

\title{
Eksistensi Perjanjian Ditengah Pandemi Covid-19
}

\author{
Kunarso ${ }^{1}$, A Djoko Sumaryanto ${ }^{2 *}$ \\ 1,2, Fakultas Hukum Universitas Bhayangkara Surabaya, Surabaya, Indonesia. \\ *E-mail: djokosumaryanto67@gmail.com
}

\begin{tabular}{|c|c|}
\hline Dikirim: 28/05/2020 & Dipublikasi: 30/10/2020 \\
\hline Info Artikel & Abstract \\
\hline $\begin{array}{l}\text { Keywords: } \\
\text { Corona Virus Disease-19; } \\
\text { Existence; Agreement. }\end{array}$ & $\begin{array}{l}\text { Corona Virus Disease-19 (COVID-19) has a significant impact on all } \\
\text { aspects of human life in the world, especially in Indonesia which is very } \\
\text { large in area and has a large population (around } 267 \text { million people) } \\
\text { with different kinds of professions. The purpose of this study is to focus } \\
\text { on civil matters, with more emphasis on the problem of agreements that } \\
\text { are influenced by Covid-19. The normative legal research method uses } \\
\text { a statutory approach, and a conceptual approach to force majeure and } \\
\text { describes an analysis (analytical descriptive). The results showed that } \\
\text { the agreement in the state of the Covid-19 outbreak greatly influenced } \\
\text { the implementation of the agreement set and agreed upon by the parties, } \\
\text { because the agreement binds the parties, so the parties are subject to the } \\
\text { contents of the agreement. }\end{array}$ \\
\hline & Abstrak \\
\hline $\begin{array}{l}\text { Kata Kunci: } \\
\text { Corona Virus Disease-19; } \\
\text { Eksistensi, Perjanjian. }\end{array}$ & $\begin{array}{l}\text { Corona Virus Disease-19 (COVID-19) berdampak signifikan } \\
\text { terhadap seluruh aspek kehidupan manusia di dunia, terutama } \\
\text { di Indonesia yang wilayahnya sangat luas dan berpenduduk } \\
\text { besar (sekitar } 267 \text { juta jiwa) dengan berbagai jenis profesi. Tujuan } \\
\text { penelitian ini memfokuskan pada masalah perdata lebih } \\
\text { menitikberatkan pada masalah adanya perjanjian yang } \\
\text { dipengaruhi oleh Covid-19. Metode penelitian hukum normatif } \\
\text { dengan pendekatan perundang-undangan, dan pendekatan } \\
\text { konseptual tentang force majeure serta mendeskripsikan suatu } \\
\text { analisis (deskriptif analitis). Hasil penelitian menunjukan bahwa } \\
\text { perjanjian dalam keadaan wabah Covid-19 sangat berpengaruh } \\
\text { terhadap pelaksanaan perjanjian yang ditetapkan dan disepakati } \\
\text { oleh para pihak, sebab perjanjian tersebut mengikat para pihak, } \\
\text { sehingga para pihak tunduk pada isi perjanjian. }\end{array}$ \\
\hline
\end{tabular}

\section{Pendahuluan}

Saat ini hampir semua negara di dunia berbicara mengenai bagaimana berupaya/berusaha untuk memutus rantai penyebaran corona virus disease tahun 2019 (Covid-19). Salah satunya Negara Indonesia, begitu banyak informasi yang simpang siur terkait covid-19 yang membuat masyarakat yang ada menjadi khawatir dan sangat takut tertular virus Corona. Rasa khawatir juga dirasakan oleh pelaku usaha, yang secara langsug berhadapan dengan masalah mendapatkan bahan baku, proses produksi, pengepakan 
barang, pendistribusian barang pada konsumen, dan lain lain, juga melanda pada bidang usaha lain, sehingga dengan adanya covid-19 tentunya kita perlu mengambil langkah yang antisipatif agar dapat meminimalisir penyebaran penyakit yang berasal dari hewan (zoonosis) tanpa harus menjauhi dan memusnahkan hewan dari muka bumi (Pesulima \& Hetharie, 2020: 282).

Pemerintah Republik Indonesia melalui Peraturan Pemerintah Pengganti Undangundang (Perpu) nomor : 1 Tahun 2020 tentang Kebijakan Keuangan dan Stabilitas Sistem Keuangan untuk Penanganan Pandemi Corona virus Disease 2019 (Covid-19), lalu dengan Undang-undang Nomor : 6 tahun 2018 tentang Karantina Wilayah, serta Peraturan Pemerintah Nomor : 21 tahun 2020 tentang Pembatasan Sosial Berskala Besar (PSBB) dalam rangka Percepatan Penanganan Covid-19. Serta dengan dikeluarkannya Keputusan Presiden (Kepres) nomor 12 Tahun 2020 tentang Penetapan Bencana Non-Alam Penyebaran Covid-19 sebagai Bencana Nasional

Kronologi Pandemi dan respon kondisi terhadap masalah ini. Hal ini juga merujuk pada beberapa fakta yang terjadi mulai dari kota Wuhan, atau respon yang akan, dan sudah dilakukan oleh pemerintah. Bahwa terdapat penyebaran Covid-19 yang sangat pesat dan Covid-19 tersebut telah di deklarasi oleh WHO sebagai pandemik, karena mengalami peningkatan yang sangat pesat secara global. Selanjutnya Pemerintah Indonesia menetapkan pandemi Covid-19 sebagai bencana nasional melalui Keputusan Presiden No. 12 tahun 2020 tentang Penetapan Bencana Non-alam Penyebaran Corona Virus Disease 2019 (Covid-19) Sebagai Bencana Nasional.

Penanggulangan bencana nasional yang diakibatkan oleh penyebaran Covid-19 dilaksanakan oleh Gugus Tugas Percepatan Penanganan Covid-19 sesuai dengan Keputusan Presiden Nomor 7 Tahun 2020 tentang Gugus Tugas Percepatan Penanganan Corona Virus Disease 2019 (COVID-19) sebagaimana telah diubah dengan Keputusan Presiden Nomor 9 Tahun 2020 tentang Perubahan atas Keputusan Presiden Nomor 7 Tahun 2020 melalui sinergi antar kementerian/lembaga dan pemerintah daerah. Selanjutnya, reaksi dan ketetapan dimana Gubernur, bupati, dan walikota sebagai Ketua Gugus Tugas Percepatan Penanganan Covid-19 di daerah, dalam menetapkan kebijakan di daerahnya harus memperhatikan kebijakan pemerintah pusat. Keputusan presiden ini mulai berlaku pada tanggal ditetapkan, yakni 13 April 2020.

Seseorang bebas untuk membuat perjanjian dengan pihak manapun yang dikehendakinya sebagaimana asas kebebasan berkontrak (Hetharie, 2019: 32), perjanjian yang dibuat secara sah dapat dilaksanakan oleh para pihak yakni para pihak dapat melaksanakan pemenuhan hak dan kewajiban yang telah diperjanjikan untuk mencapai tujuan dari perjanjian tersebut (Aminah, 2020: 652), namun dengan adanya penetapan Bencana Non-Alam penyebaran Covid-19 sebagai Bencana Nasional menurut Keputusan Presiden No. 12 tahun 2020, menjadikan suatu tanda akan eksistensi suatu perjanjian. Apakah keadaan dalam penetapan Bencana Non-Alam Penyebaran Covid-19 termasuk dalam keadaan Kahar?. Adapun Keadaan kahar (bahasa perancis : force majeure yang berarti "kekuatan yang lebih besar") adalah suatu kejadian yang terjadi di luar kemampuan manusia dan tidak dapat dihindarkan sehingga suatu kegiatan tidak dapat dilaksanakan atau tidak dapat dilaksanakan (Wikipedia, n.d.-b) sebagaimana ditetapkan dalam setiap perjanjian atau kontrak.

Klausul force majeure, ini hampir selalu ada dalam perjanjian yang dibuat. Sedangkan perjanjian adalah suatu perbuatan dimana satu orang atau lebih mengikatkan diri terhadap satu orang lain atau lebih. Meurut Pasal 1320 KUH Perdata suatu perjanjian harus memenuhi 
4 (empat) syarat agar dapat memiliki kekuatan hukum dan mengikat para pihak yang membuatnya, yaitu 1. Sepakat mereka yang mengikatkan diri, 2. Kecakapan untuk membuat suatu perikatan, 3. Mengenai suatu hal tertentu, dan 4. Suatu sebab yang halal.

Dalam membuat suatu bisnis, pelaku usaha diwajibkan untuk selalu membaca dengan hati-hati mengenai seluruh klausul yang terdapat dalam perjanjian. Dari sekian banyak klausul yang terdapat dalam perjanjian, terdapat satu klausul yang selalu ada yaitu klausul mengenai keadaan kahar atau force majeure. Klausul ini ada karena adanya kebutuhan pengaturan untuk hal-hal yang mungkin terjadi dimasa yang akan datang yang dapat berpotensi untuk menimbulkan konflik antara para pihak dalam perjanjian.

Force majeure sering dikaitkan dengan suatu kejadian yang disebabkan oleh kekuatan yang lebih besar biasanya berupa gempa bumi, banjir, gunung meletus, perang, kerusuhan, tindakan pemerintah, tindakan teroris dan lain-lain, yang menghalangi pihak untuk berprestasi terkait suatu perjanjian. Akibat tidak adanya suatu definisi yang tegas terhadap keadaan kahar atau force majeure sehingga beragam interpretasi muncul termasuk dari para ahli hukum sehingga tidak jarang perbedaan interpretasi tersebut dapat menimbulkan masalah dikemudian hari, seperti saat ini dengan adanya Covid-19.

Istilah gagal bayar atau wanprestasi (Wikipedia, n.d.-a) dikenal dan dipergunakan dalam dunia keuangan untuk menggambarkan suatu keadaan dimana seorang debitur tidak dapat memenuhi kewajibannya. Adapun bentuk wanprestasi dapat terwujud dalam beberapa bentuk (Muljadi \& Wijaya, 2004: 70), yaitu

1) Debitor sama sekali tidak melaksanakan kewajibannya ;

2) Debitor tidak melaksanakan kewajibannya sebagaimana mestinya/melaksanakan kewajibannya tetapi tidak sebagaimana mestinya ;

3) Debitur tidak melaksanakan kewajibannya pada waktunya ;

4) Debitur melaksanakan sesuatu yang tidak diperbolehkan

Adapun beberapa bentuk usaha yang mengalami kesulitan memenuhi prestasinya Seperti usaha di bidang Hotel dan restoran, berdasarkan survey sentimen pasar Hotel dan Restoran Indonesia terhadap pengaruh Covid-19 pada bulan Maret 2020 (PHNRI \& Horwath HTL, n.d.) (PHRI dan Howath HTL), tingkat okupasi hotel turun 25-50\% dengan total pendapatan turun pada kisaran 25-50 \%. Demikian juga pada sektor restoran, total pendapatan turun 25-50 \%. Pada sektor perbankkan, Otoritas Jasa Keuangan (OJK) merilis data bahwa per-tanggal 27 Maret 2020 profil resiko masih terjaga dengan Non Performing Loan (NPL) groos sebesar 2,79\%,

Lebih jauh, para pelaku usaha baik sebagai supllier, penyedia jasa, pemberi jasa, distributor dan konsumen, akan mengalami situasi yang kurang kondusif pada masa pandemik Covid-19. Bagi debitur, penurunan Omset akibat berkurangnya permintaan akan berdampak pada kemampuan membayar kredit kepada kreditur, bahkan bisa mengakibatkan gagal bayar berkenaan dengan hal tersebut Otoritas Jasa Keuangan (OJK) mengeluarkan Peraturan OJK No. 11 tahun 2020, tentang Stimulus Perekonomian Nasional sebagai kebijakan Countercylical dampak penyebaran Covid-19. Adapun jenis debitur yang dapat diberikan stimulus adalah yang bergerak pada sektor ekonomi antara lain Pariwisata, transportasi, perhotelan, perdagangan, pengolahan, pertanian, dan pertambangan. Namun perlu dicatat bahwa kebijakan restrukturisasi/keringanan kredit/pembiayaan diserahkan kepada pihak bank, artinya Bank yang akan melakukan Self-assesment dengan pedoman paling sedikit memuat kriteria debitur dan sektor yang terkena dampak Covid-19. 
Maksud dan tujuan dari penulisan ini adalah ingin mengkaji keberadaan perjanjian ditengah pandemi Covid-19 dengan situasi dan kondisi masyarakat supaya bekerja dari rumah, belajar dirumah, beribadah dirumah, menghindari kerumunan dan lain-lain sangat berdampak pada eksistensi perjanjian, artinya apakah situasi dan kondisi yang dilanda pandemi Covid-19 ini bisa dikategorikan sebagai keadaan kahar atau force majeure sehingga dapat mempengaruhi eksistensi perjanjian ?, dalam tulisan ini akan dikaji keadaan kahar tersebut.

Penulisan ini memfokuskan pada eksistensi perjanjian ditengah pandemi Covid-19, sedangkan tulisan sebelumnya juga mengkaji hal yang sama namun dari perspektif yang berbeda, dibuat oleh Agri Chairunisa Isradjuningtyas yang diterbitkan dalam e-journal. Unpar.ac.id dari Universitas Parahiyanan Bandung tahun 2015 yang berjudul Force Majeure (Overmach) dalam hukum kontrak (perjanjian) Indonesia

\section{Metode Penelitian}

Metode penelitian menggunakan jenis penelitian hukum normatif, yaitu suatu jenis penelitian yang mengkaji suatu aturan perundang-undangan atau norma yang mempunyai kekuatan hukum. Dalam penulisan skripsi ini Undang-Undang yang digunakan, Peraturan Pemerintah Pengganti Undang-undang (Perpu) nomor 1 tahun 2020 tentang Kebijakan Keuangan dan Stabilitas Sistem Keuangan untuk Penanganan Pandemi Covid-19, Peraturan Pemerintah (PP) No. 21 tahun 2020 tentang Pembatasan Sosial Berskala Besar, serta Keputusan Presiden (Kepres) no. 12 tahun 2020 tentang Penetapan Bencana Non-Alam Penyebaran Covid-19 sebagai Bencana Nasional. Pendekatan masalah yang digunakan dalam penelitian ini adalah pendekatan Undang-Undang (statute approach) dan Konsep (conceptual approach) yang terkait dengan normatif yang mengutamakan pada aturan hukum dipadukan dengan menelaah fakta-fakta sosial (keadaan kahar/force majeure) terkait dengan masalah penelitian.

\section{Hasil dan Pembahasan}

\subsection{Keabsahan suatu Perjanjian}

Perjanjian sah atau tidak sah, maka perjanjian tersebut harus diuji dengan beberapa syarat. Pasal 1320 KUHPerdata menentukan empat syarat untuk sahnya suatu perjanjian, Yaitu :

a. Sepakat mereka yang mengikatkan dirinya

b. Kecakapan untuk membuat suatu perikatan

c. Suatu hal tertentu

d. Suatu sebab yang halal

Syarat pertama dan kedua disebut sebagai syarat subyektif karena kedua syarat tersebut harus dipenuhi oleh subyek hukum. Sedangkam syarat ketiga dan keempat disebut sebagai syarat obyektif karena kedua syarat ini harus dipenuhi oleh obyek perjanjian (Komariah, 2002: 175-177), tidak terpenuhinya syarat subyektif akan mengakibatkan suatu perjanjian menjadi dapat dibatalkan, maksudnya ialah perjanjian tersebut manjadi batal demi hukum. Artinya sejak semula dianggap tidak pernah dilahirkan suatu perjanjian dan tidak pernah ada suatu perikatan.

Sepakat mereka yang mengikatkan dirinya, maksudnya ialah para pihak yang terlibat dalam perjanjian harus sepakat atau setuju mengenai hal-hal pokok dari perjanjian tersebut. 
Pasal 1321 KUHPerdata menentukan bahwa "kata sepakat tidak sah apabila diberikan karena kekhilafan atau diperoleh dengan paksaan atau penipuan"

Kecakapan untuk membuat suatu perikatan, Pada Pasal 1330 KUH Perdata menentukan bahwa "setiap orang adalah Cakap untuk membuat perikatan, kecuali undang-undang menentukan bahwa ia tidak cakap". Mengenai orang-orang yang tidak cakap untuk membuat perjanjian dapat kita temukan dalam Pasal 1330 KUH Perdata, yaitu

a) Orang-orang yang belum dewasa,

b) Mereka yang ditaruh dibawah pengampuan,

c) Orang-orang perempuan yang telah kawin. Ketentuan ini menjadi hapus dengan berlakunya Undang-undang Nomor 1 tahun 1974 tentang Perkawinan. Karena Pasal 31 Undang-undang ini menentukan bahwa hak dan kedudukan suami istri adalah seimbang dan masing-masing berhak untuk melakukan perbuatan hukum.

Suatu hal tertentu, mengenai hal ini dapat kita temukan dalam Pasal 1332 KUH Perdata. Pasal 1332 KUHPerdata menentukan bahwa "hanya barang-barang yang dapat diperdagangkan saja dapat menjadi pokok suatu perjanjian". Sedangkan Pasal 1333 KUH Perdata menentukan : "suatu perjanjian harus mempunyai sebagai pokok suatu barang yang paling sedikit ditentukan jenisnya. Tidaklah menjadi halangan bahwa jumlah barang tidak tentu, asal saja jumlah itu terkemudian dapat ditentukan atau dihitung"

Suatu sebab yang diperkenankan, maksudnya ialah isi dari perjanjian tidak dilarang oleh Undang-undang atau tidak bertentangan dengan kesusilaan atau ketertiban umum (Pasal 1337 KUHPerdata). Selain itu Pasal 1335 KUHPerdata juga menantukan bahwa "suatu perjanjian yang dibuat tanpa sebab atau dibuat karena suatu sebab yang palsu atau terlarang adalah tidak mempunyai kekuatan hukum".

Selanjutnya akan disampaikan asas-asas perjanjian, sebagai berikut: dalam sistem pengaturan hukum kontrak mengatakan bahwa Hukum kontrak adalah bagian hukum perdata (privat). Hukum ini memusatkan perhatian pada kewajiban untuk melaksanakan kewajiban sendiri (self imposed obligation). Disebut sebagai bagian dari hukum perdata disebabkan karena pelanggaran terhadap kewajiban-kewajiban yang ditentukan dalam kontrak, murni menjadi urusan pihak-pihak yang berkontrak (Muhtarom, 2014: 50)

Kontrak, dalam bentuk yang paling klasik, dipandang sebagai ekspresi kebebasan manusia untuk memilih dan mengadakan perjanjian. Kontrak merupakan wujud dari kebebasan (freedom of contract) dan kehendak bebas untuk memilih (freedom of choice). Sejak abad ke-19 prinsip-prinsip itu mengalami perkembangan dan berbagai pergeseran penting. Pergeseran demikian disebabkan oleh: pertama, tumbuhnya bentuk-bentuk kontrak standar; kedua, berkurangnya makna kebebasan memilih dan kehendak para pihak, sebagai akibat meluasnya campur tangan pemerintah dalam kehidupan rakyat; ketiga, masuknya konsumen sebagai pihak dalam berkontrak. Ketiga faktor ini berhubungan satu sama lain (Muhtarom, 2014: 50). Tetapi, prinsip kebebasan berkontrak dan kebebasan untuk memilih tetap dipandang sebagai prinsip dasar pembentukan kontrak. Menurut Dora Kusumastuti, bahwa kebebasan berkontrak bukanlah merupakan kebebasan yang sebebas-bebasnya, melainkan kebebasan tersebut haruslah mencerminkan itikad baik, yang dimulai sejak pra kontrak, yang dilanjutkan dalam pelaksanaan kontrak dan pasca kontrak (Kusumastuti, 2014: 36).

Asas-Asas Hukum Kontrak Berdasarkan teori, di dalam suatu hukum kontrak terdapat 5 (lima) asas yang dikenal menurut ilmu hukum perdata. Kelima asas itu antara lain adalah: asas kebebasan berkontrak (freedom of contract), asas konsensualisme (concsensualism), asas 
kepastian hukum (pacta sunt servanda), asas itikad baik (good faith), dan asas kepribadian (personality). Berikut ini adalah penjelasan mengenai asas-asas dimaksud (Muhtarom, 2014: 55-55):

1) Asas Kebebasan Berkontrak (freedom of contract) Asas kebebasan berkontrak dapat dianalisis dari ketentuan Pasal 1338 ayat (1) KUHPerdata, yang berbunyi: "Semua perjanjian yang dibuat secara sah berlaku sebagai undang-undang bagi mereka yang membuatnya." Asas ini merupakan suatu asas yang memberikan kebebasan kepada para pihak untuk: (1) membuat atau tidak membuat perjanjian; (2) mengadakan perjanjian dengan siapa pun; (3) menentukan isi perjanjian, pelaksanaan, dan persyaratannya, serta (4) menentukan bentuk perjanjiannya apakah tertulis atau lisan.

2) Asas Konsensualisme (concensualism) Asas konsensualisme dapat disimpulkan dalam Pasal 1320 ayat (1) KUHPerdata. Pada pasal tersebut ditentukan bahwa salah satu syarat sahnya perjanjian adalah adanya kata kesepakatan antara kedua belah pihak. Asas ini merupakan asas yang menyatakan bahwa perjanjian pada umumnya tidak diadakan secara formal, melainkan cukup dengan adanya kesepakatan kedua belah pihak. Kesepakatan adalah persesuaian antara kehendak dan pernyataan yang dibuat oleh kedua belah pihak.

3) Asas Kepastian Hukum (pacta sunt servanda) Asas kepastian hukum atau disebut juga dengan asas pacta sunt servanda merupakan asas yang berhubungan dengan akibat perjanjian. Asas pacta sunt servanda merupakan asas bahwa hakim atau pihak ketiga harus menghormati substansi kontrak yang dibuat oleh para pihak, sebagaimana layaknya sebuah undang-undang. Mereka tidak boleh melakukan intervensi terhadap substansi kontrak yang dibuat oleh para pihak. Asas pacta sunt servanda dapat disimpulkan dalam Pasal 1338 ayat (1) KUHPerdata. Dalam perkembangannya asas pacta sunt servanda diberi arti sebagai pactum, yang berarti sepakat yang tidak perlu dikuatkan dengan sumpah dan tindakan formalitas lainnya. Sedangkan istilah nudus pactum sudah cukup dengan kata sepakat saja.

4) Asas Itikad Baik (good faith) Asas itikad baik tercantum dalam Pasal 1338 ayat (3) KUHPerdata yang berbunyi: "Perjanjian harus dilaksanakan dengan itikad baik." Asas ini merupakan asas bahwa para pihak, yaitu pihak kreditur dan debitur harus melaksanakan substansi kontrak berdasarkan kepercayaan atau keyakinan yang teguh maupun kemauan baik dari para pihak. Asas itikad baik terbagi menjadi dua macam, yakni itikad baik nisbi dan itikad baik mutlak. Pada itikad yang pertama, seseorang memperhatikan sikap dan tingkah laku yang nyata dari subjek. Pada itikad yang kedua, penilaian terletak pada akal sehat dan keadilan serta dibuat ukuran yang obyektif untuk menilai keadaan (penilaian tidak memihak) menurut norma-norma yang objektif.

5) Asas Kepribadian (personality) Asas kepribadian merupakan asas yang menentukan bahwa seseorang yang akan melakukan dan/atau membuat kontrak hanya untuk kepentingan perseorangan saja. Hal ini dapat dilihat dalam Pasal 1315 dan Pasal 1340 KUHPerdata. Pasal 1315 KUHPerdata menegaskan: "Pada umumnya seseorang tidak dapat mengadakan perikatan atau perjanjian selain untuk dirinya 
sendiri." ketentuan ini sudah jelas bahwa untuk mengadakan suatu perjanjian, orang tersebut harus untuk kepentingan dirinya sendiri. Pasal 1340 KUHPerdata berbunyi: "Perjanjian hanya berlaku antara pihak yang membuatnya." Hal ini mengandung maksud bahwa perjanjian yang dibuat oleh para pihak hanya berlaku bagi mereka yang membuatnya. Namun demikian, ketentuan itu terdapat pengecualiannya sebagaimana diintridusir dalam Pasal 1317 KUHPerdata yang menyatakan: "Dapat pula perjanjian diadakan untuk kepentingan pihak ketiga, bila suatu perjanjian yang dibuat untuk diri sendiri, atau suatu pemberian kepada orang lain, mengandung suatu syarat semacam itu." Pasal ini mengkonstruksikan bahwa seseorang dapat mengadakan perjanjian/ kontrak untuk kepentingan pihak ketiga, dengan adanya suatu syarat yang ditentukan. Sedangkan di dalam Pasal 1318 KUHPerdata, tidak hanya mengatur perjanjian untuk diri sendiri, melainkan juga untuk kepentingan ahli warisnya dan untuk orang-orang yang memperoleh hak daripadanya. Jika dibandingkan kedua pasal itu, maka Pasal 1317 KUHPerdata mengatur tentang perjanjian untuk pihak ketiga, sedangkan dalam Pasal 1318 KUHPerdata untuk kepentingan dirinya sendiri, ahli warisnya dan orang-orang yang memperoleh hak dari yang membuatnya. Dengan demikian, Pasal 1317 KUHPerdata mengatur tentang pengecualiannya, sedangkan Pasal 1318 KUHPerdata memiliki ruang lingkup yang luas.

Asas-Asas Hukum Perikatan Nasional di samping kelima asas yang telah diuraikan di atas, dalam Lokakarya Hukum Perikatan yang diselenggarakan oleh Badan Pembinaan Hukum Nasional (BPHN), Departemen Kehakiman RI pada tanggal 17-19 Desember 1985 telah berhasil dirumuskannya delapan asas hukum perikatan nasional (Muhtarom, 2014: 54). Kedelapan asas tersebut adalah: asas kepercayaan, asas persamaan hukum, asas keseimbangan, asas kepastian hukum, asas moralitas, asas kepatutan, asas kebiasaan, dan asas perlindungan. Adapun penjelasannya adalah sebagai berikut:

1) Asas Kepercayaan, yaitu bahwa setiap orang yang akan mengadakan perjanjian akan memenuhi setiap prestasi yang diadakan di antara mereka di belakang hari.

2) Asas Persamaan Hukum, yaitu bahwa subjek hukum yang mengadakan perjanjian mempunyai kedudukan, hak dan kewajiban yang sama dalam hukum. Mereka tidak boleh dibeda-bedakan antara satu sama lainnya, walaupun subjek hukum itu berbeda warna kulit, agama, dan ras.

3) Asas Keseimbangan, yaitu asas yang menghendaki kedua belah pihak memenuhi dan melaksanakan perjanjian. Kreditur mempunyai kekuatan untuk menuntut prestasi dan jika diperlukan dapat menuntut pelunasan prestasi melalui kekayaan debitur, namun debitur memikul pula kewajiban untuk melaksanakan perjanjian itu dengan itikad baik.

4) Asas Kepastian Hukum, yaitu asas ini mengandung maksud bahwa perjanjian sebagai figur hukum mengandung kepastian hukum. Kepastian ini terungkap dari kekuatan mengikatnya perjanjian, yaitu sebagai undang-undang bagi yang membuatnya.

5) Asas Moralitas, adalah asas yang berkaitan dengan perikatan wajar, yaitu suatu perbuatan sukarela dari seseorang tidak dapat menuntut hak baginya untuk menggugat prestasi dari pihak debitur. Hal ini terlihat dalam zaakwarneming, yaitu seseorang melakukan perbuatan dengan sukarela (moral), yang bersangkutan 
mempunyai kewajiban hukum untuk meneruskan dan menyelesaikan perbuatannya. Salah satu faktor yang memberikan motivasi pada yang bersangkutan melakukan perbuatan hukum itu adalah didasarkan pada kesusilaan (moral) sebagai panggilan hati nuraninya.

6) Asas Kepatutan, yaitu asas yang tertuang dalam Pasal 1339 KUHPerdata. Asas ini berkaitan dengan ketentuan mengenai isi perjanjian yang diharuskan oleh kepatutan berdasarkan sifat perjanjiannya.

7) Asas Kebiasaan, yaitu dipandang sebagai bagian dari perjanjian. Suatu perjanjian tidak hanya mengikat untuk apa yang secara tegas diatur, akan tetapi juga hal-hal yang menurut kebiasaan lazim diikuti.

8) Asas Perlindungan, yaitu asas yang mengandung pengertian bahwa antara debitur dan kreditur harus dilindungi oleh hukum. Namun, yang perlu mendapat perlindungan itu adalah pihak debitur karena pihak ini berada pada posisi yang lemah. Asas-asas inilah yang menjadi dasar pijakan dari para pihak dalam menentukan dan membuat suatu kontrak/ perjanjian dalam kegiatan hukum sehari-hari.

Dengan demikian, dapat dipahami bahwa keseluruhan asas di atas merupakan hal penting dan mutlak harus diperhatikan bagi pembuat kontrak/ perjanjian, sehingga tujuan akhir dari suatu kesepakatan dapat tercapai dan terlaksana sebagaimana diinginkan oleh para pihak

\subsection{Penetapan Bencana Non-Alam Penyebaran Covid-19 sebagai Force Majure}

Telah dipahami bersama bahwa Covid-19 adalah bencana yang melanda masyarakat Dunia Pemerintah Indonesia telah menetapkan Covid-19 sebagai jenis penyakit yang menimbulkan kedaruratan kesehatan masyarakat. Oleh karena itu, dalam rangka menghambat penyebaran COVID-19, Pemerintah mengambil langkah dengan menetapkan pandemi Covid-19 sebagai bencana nasional dan mengimbau masyarakat untuk melakukan Social Distancing, Physical Distancing serta bekerja, belajar, beribadah dari rumah. Imbauan Pemerintah ini diikuti dengan dikeluarkannya sejumlah payung hukum diantaranya, Peraturan Pemerintah Nomor 21 Tahun 2020 tentang PSBB Dalam Rangka Percepatan Penanganan Covid-19, Keputusan Presiden Nomor 11 Tahun 2020 tentang Penetapan Kedaruratan Kesehatan Masyarakat Covid-19, Peraturan Menteri Kesehatan Republik Indonesia Nomor 9 Tahun 2020 tentang Pedoman PSBB Dalam Rangka Percepatan Penanganan Covid-19. Terakhir, melalui Keputusan Presiden Nomor 12 Tahun 2020 tentang Penetapan Bencana Non Alam Penyebaran Covid-19 Sebagai Bencana Nasional.

Persoalan keadaan kahar atau force majeure menjadi perbincangan dan kajian bagi praktisi hukum akhir-akhir ini. Penyebabnya terdapat spekulasi publik khususnya pelaku usaha yang menganggap Kepres no. 12 tahun 2020 tentang penetapan Bencana Non-Alam penyebaran Covid-19 sebagai dasar hukum force majeure. Alasan bencara adalah sebagai sebuah force majeure, kejadian luar biasa yang menyebabkan orang tidak mampu memenuhi prestasinya karena peristiwa yang di luar kemampuannya, sehingga perjanjian-perjanjian kontrak keperdataan secara otomatis dapat diubah atau dibatalkan.

Peneliti Fornano \& Wolf, menyebutkan bahwa "the coronavirus outbreak will cause a negative supply shock to the world economy, by forcing factories to shut down and disrupting global supply chains". Institute for Development of Economics and Finance (INDEF) kemudian mengabstraksikan hasil penelitian Fornano \& Wolf tersebut dalam bahasa yang lebih sederhana bahwa pandemi Covid-19 ini diprediksi akan menyebabkan guncangan sisi 
penawaran-permintaan yang meliputi penurunan produksi barang, penurunan pendapatan, gelombang pemutusan hubungan kerja, penurunan daya beli, penurunan permintaan atas barang.

Lebih jauh, para pelaku usaha baik sebagai supplier, penyedia jasa, pemberi jasa, distributor dan konsumen akan mengalami situasi yang kurang kondusif pada masa pandemik Covid-19. Bagi debitur, penurunan pendapatan (omzet) akibat berkurangnya permintaan akan berdampak pada kemampuan membayar kredit kepada kreditur, bahkan bisa mengakibatkan gagal bayar. Sehubungan dengan hal ini, OJK menerbitkan Peraturan Otoritas Jasa Keuangan Nomor 11/POJK.03/2020 tentang Stimulus Perekonomian Nasional Sebagai Kebijakan Countercylical Dampak Penyebaran Covid-19 (selanjutnya disebut POJK No. 11/2020).

Menurut POJK No. 11/2020, Bank dapat memberikan restrukturisasi/keringanan kredit/pembiayaan kepada debitur. Syaratnya, debitur dimaksud terkena dampak penyebaran Covid-19, baik secara langsung maupun tidak langsung yang mengakibatkan debitur mengalami kesulitan untuk memenuhi kewajiban pada Bank (bank umum konvensional, termasuk unit usaha syariah, bank umum syariah, bank perkreditan rakyat, bank pembiayaan rakyat syariah). Adapun jenis usaha debitur yang dapat diberikan stimulus adalah yang bergerak pada sektor ekonomi antara lain pariwisata, transportasi, perhotelan, perdagangan, pengolahan, pertanian, dan pertambangan. Namun, patut dicatat, kebijakan restrukturisasi/keringanan kredit/pembiayaan diserahkan kepada pihak Bank.

Menurut Black's Law Dictionary, force majeur adalah "an event or effect that can be neither anticipated nor controlled". Dalam hukum perdata materiil Indonesia, istilah force majeure memang tidak diatur secara tegas. Namun di dalam Pasal 1245 KUHPerdata disebutkan bahwa " pihak dalam suatu perikatan tidak diwajibkan memberikan ganti rugi apabila pihak tersebut terhalang memenuhi kewajibannya karena adanya keadaan memaksa (overmacht). Dari ketentuan Pasal 1245 KUHPerdata dan Black's Law Dictionary tersebut, terdapat benang merah yakni pihak tidak dapat diminta ganti rugi dalam hal terdapat keadaan yang tidak dapat diperkirakan sebelumnya atau diluar kendali yang wajar karena adanya faktor eksternal. Dalam konteks pandemi Covid-19, apakah keadaan kahar (force majeure) dapat terpenuhi secara hukum? Atau, apakah klaim force majeure tetap harus merujuk pada perjanjian yang disepakati para pihak?

Ketentuan Pasal 1245 KUHPerdata tercantum di dalam Buku Ketiga tentang Perikatan Bab I tentang Perikatan Pada Umumnya. Artinya, ketentuan Pasal 1245 KUH Perdata sejatinya berlaku bagi para pihak dalam suatu perikatan dengan syarat, pertama, para pihak menundukkan diri bahwa hukum perdata yang berlaku di Indonesia sebagai governing law; dan kedua, para pihak tidak mengatur secara khusus mengenai klausula force majeure dalam perikatan.

Keadaan memaksa ini pula mengarahkan kepada teori penghapusan atau peniadaan kesalahan (afwesigheid van schuld), teori memberikan keringanan terhadap debitur untuk tidak bertanggungjawab terhadap suatu kewajiban yang seharusnya dilakukan, karena kesalahan tersebut bukan berasal dari debitur. Teori ini memberikan arahan bahwa Pertama, debitur tidak perlu membayar ganti rugi (Pasal 1244 KUHPerdata). Kedua, beban resiko tidak berubah terutama pada keadaan memaksa sementara. Ketiga, kreditur tidak berhak atas pemenuhan prestasi, tetapi bersamaan dengan pembebasan dari kewajibannya untuk menyerahkan kontra prestasi, kecuali terhadap Pasal 1460 KUHPerdata (Salim \& Nurbani, 2014: 264). 
Praktisi hukum, Ricardo Simanjuntak, berpendapat bahwa terlepas apakah para pihak dalam suatu perjanjian mengatur mengenai pandemi sebagai alasan force majeure, ketentuan Pasal 1245 KUHPerdata tetap berlaku dan harus dipatuhi. Ricardo menambahkan, dalam konteks pandemi Covid-19, force majeure dapat diklaim karena para pihak tidak dapat memprediksi pandemi dan tidak memiliki contributory effect serta pandemi ini menjadi suatu halangan yang terjadi secara umum (Hukum Online.com, n.d.).

Pendapat lainnya Rahayu Ningsih Hoed, Senior Partner dari lawfirm ternama, berpendapat bahwa pandemi Covid-19 termasuk sebagai suatu keadaan kahar tergantung dari definisi keadaan memaksa (apabila ada) di dalam perjanjian. Menurutnya, jenis klausul keadaan memaksa terdiri dari 2 (dua) klausul, pertama, klausul tidak eksklusif dimana suatu pihak dapat mengklaim force majeure sepanjang adanya kondisi yang disetujui untuk berlakunya force majeure dan kedua, klausul ekskusif dimana keadaan memaksa terbatas pada keadaan-keadaan yang disebutkan di dalam perjanjian (KlikLegal.com, n.d.).

Abdul Salam, Dosen Fakultas Hukum Universitas Indonesia menjelaskan Pasal 1245 KUHPerdata itu masuk dalam bagian Buku III KUHPerdata yang sifatnya melengkapi perjanjian. Artinya, sepanjang para pihak tidak mengatur sebaliknya, maka ketentuan Buku III itu, khususnya terkait force majeure, akan berlaku. Bila perjanjian misalnya mengatur pandemi bukan bagian dari force majeure, maka harus berlaku demikian. "Akan tetapi, kalau tidak diperjanjikan para pihak, maka pandemi itu bisa dianggap force majeure,". Force majeure atau keadaan memaksa memiliki dua sifat, yakni umum dan khusus. Force majeur yang sifatnya umum berkaitan dengan act of god, sementara force majeure yang bersifat khusus berhubungan dengan act of human (Hukum Online.com, n.d.).

Berhubung dalam kasus pandemik corona pemerintah Indonesia mengeluarkan aturan, maka force majeure konteks corona masuk dalam kategori khusus (act of human). Jika dilihat dari segi posisi kasus, dikenal pula force majeure relatif yang unsurnya difficulty (kesulitan), dan force majeur absolut yang memiliki anasir impossibility (ketidakmungkinan). "Kalau corona ini, para pihak masih bisa melakukan pekerjaan, tapi sulit, karena takut tertular virus. Jadi ukurannya bukan impossible, tapi difficulties,".

Pada praktiknya, para pihak dalam perjanjian akan mencantumkan klausula force majeure dan lazimnya ruang lingkup force majeure didefinisikan lebih rinci. Salah satu contoh klausula force majeure, sebagai berikut:

"Apabila terjadi keterlambatan dan/atau tidak dapat dilaksanakannya kewajiban yang tercantum dalam Perjanjian ini oleh salah satu pihak yang disebabkan kejadian di luar kemampuan atau kehendak pihak yang bersangkutan (force majeure), maka keterlambatan dan/atau kegagalan tersebut tidak dapat dianggap sebagai kelalaian/kesalahan dari pihak yang bersangkutan. Pihak-Pihak yang bersangkutan akan dilindungi atau tidak akan mengalami tuntutan dari pihak lainnya".

Sebagai alternatif, ada juga klausula force majeure yang secara tegas menyebutkan pandemi sebagai alasan force majeure. Misalnya, ketentuan force majeure yang ada dalam Syarat dan Ketentuan (Terms and Conditions) yang diberlakukan oleh salah satu perusahaan penyedia layanan pemesanan hotel dan tiket transportasi, sebagai berikut:

“Kami tidak bertanggung-jawab ataupun menanggung kerugian Anda dalam hal Kami tidak dapat menyerahkan Produk atau memberi Layanan kepada Anda, akibat dari hal-hal yang terjadi akibat keadaan memaksa atau yang diluar kekuasaan Kami atau Mitra Penyedia Kami untuk mengendalikan, seperti, tapi tidak terbatas pada: perang, 
kerusuhan, teroris, perselisihan industrial, tindakan pemerintah, epidemik, pandemik, bencana alam, kebakaran atau banjir, cuaca ekstrim, dan lain sebagainya".

Menurut Rahmat S.S. Soemadipradja bila diperbandingkan dengan lingkup force majeure yang diatur di dalam KUHPerdata maka ada perkembangan yang terjadi, bahwa lingkup force majeure tidak lagi terbatas pada peristiwa alam atau act of God, dan hilangnya objek yang diperjanjikan, tetapi sudah meluas kepada tindakan administratif penguasa, kondisi politik seperti perang. Ruang lingkup atau jenis peristiwa tersebut meliputi (Soemadipradja, 2010: 120):

1) Resiko perang, kehilangan benda objek perjanjian yang disebabkan dari kuasa Yang Maha Besar: disambar halilintar, kebakaran, dirampas tentara Jepang dalam masa perang (Putusan MA RI No. Reg. 15 K/Sip/1957);

2) Act of God, tindakan administratif penguasa, perintah dari yang berkuasa, keputusan, segala tindakan administratif yang menentukan atau mengikat, suatu kejadian mendadak yang tidak dapat diatasi oleh pihak-pihak dalam perjanjian (Putusan MA RI No. 3389 K/Pdt/1984);

3) Peraturan-peraturan pemerintah (Putusan MA RI No. Reg. 24 K/Sip/1958); Baik PN maupun PT menyatakan bahwa apa yang dikemukakan oleh tergugat Super Radio Company NV tidak dapat dipergunakan sebagai alasan force majeure karena apabila tergugat tidak bisa mendapatkan motor AJS dari NV Danau karena keluarnya peraturan-peraturan pemerintah (KPUI) tentang larangan untuk mengimpor lebih dari satu merek motor maka untuk memenuhi kewajibannya terhadap penggugat, ia harus berikhtiar/berusaha mendapatkan sepeda motor itu dari NV Ratadjasa atau dengan jalan lain, asal tidak dengan cara melanggar hukum. Baik PN maupun PT menyatakan bahwa tergugat Super Radio Company NV telah melalaikan kewajibannya.

4) Kecelakaan di laut, misalnya kapal tenggelam karena ombak besar memukul lambung kapal (Putusan MA RI No. 409 K/Sip/1983);

5) Keadaan darurat (Putusan MA RI No. Reg. 1180 K/Sip/1971);

6) Situasi atau keadaan yang sama sekali tidak dapat diduga dan/atau yang sangat memaksa yang terjadi di luar kekuasaan pihak yang harus berprestasi (Putusan No. 21/Pailit/2004/PN.Niaga.Jkt.Pst).

Namun demikian menurut pemerintah yang diwakili oleh Menteri koordinator Bidang Politik, Hukum dan Hak Asasi Manusia Mahfud MD (Mahfud MD, n.d.), mengatakan bahwa anggapan Kepres No 12 tahun 2020 sebagai dasar untuk membatalkan kontrakkontrak keperdataan, terutama kontrak bisnis merupakan kekeliruan. Didalam hukum perjanjian memamg ada ketentuan bahwa force majeure bisa dijadikan alasan untuk membatalkan kontrak, spekulasi tersebut keliru dan meresahkan, bukan hanya dalam dunia usaha tetapi juga bagi pemerintah, itu sebabnya saya sebagai salah satu seorang pejabat yang ikut bertanggung jawab atas kebijakan negara segera angkat bicara dan menegaskan bahwa status Covid-19 sebagai bencana non-alam tidak bisa langsung dijadikan alasan pembatalan kontrak dengan alasan force majeure.

\subsection{Eksistensi Perjanjian Ditengah Covid-19}

Sebagaimana telah disampaikan sebelumnya, dampak pandemi Covid-19 ini dirasakan oleh para pelaku usaha dalam siklus supply-demmand tidak terkecuali bagi pemberi dan penyedia jasa serta kreditur dan debitur dalam perjanjian kredit. Oleh karena itu, pengajuan klaim force majeure seyogianya dilakukan dengan semangat untuk bersama-sama memenuhi 
kewajiban masing-masing pihak dengan cara-cara terbaik. Oleh karena itu, klaim implementasi force majeure dari satu kasus ke kasus yang lain mungkin saja berbeda (case by case basis). Ada beberapa pertimbangan dalam mengajukan klaim force majeure, diantaranya:

1) Klaim force majeure diajukan dengan itikad baik dan sesuai tata cara pemberitahuan yang disepakati dalam perjanjian. Para pihak dalam suatu perikatan perlu memahami bahwa asas itikad baik tidak hanya berlaku pada saat pelaksanaan perjanjian, namun sejak persiapan perjanjian (pre-contract), pelaksanaan perjanjian (during the period of contract), dan penyelesaian sengketa (disputes settlement). Meskipun secara faktual terdampak pandemi Covid-19, pihak yang mengklaim force majeure harus dengan itikad baik berusaha melakukan hal-hal yang dianggap patut dan wajar untuk tetap melaksanakan kewajiban atau paling tidak melakukan upaya untuk memitigasi risiko tidak terpenuhinya kewajiban berdasarkan perjanjian. Kemudian terkait tata cara pemberitahuan, umumnya ditentukan bahwa pihak yang mengalami/terdampak force majeure harus memberitahukan secara tertulis kepada pihak lain dalam kurun waktu tertentu sejak dampak tersebut dirasakan.

2) Klaim force majeure didasarkan pada rujukan hukum yang tepat. Pihak yang mengajukan klaim harus terlebih dahulu meneliti apakah bencana, pandemi atau tindakan pemerintah pemberlakuan aturan tertentu termasuk ruang lingkup force majeure yang diakomodasi dalam perjanjian. Apabila, klaim force majeure didasarkan pada adanya tindakan pemerintah, pihak yang mengklaim dianjurkan untuk membuktikan bahwa adanya tindakan pemerintah tersebut secara nyata berdampak pada kegiatan/ aktivitas bisnisnya. Misalnya, dalam konteks PSBB yang diberlakukan di Provinsi DKI Jakarta dan beberapa wilayah kabupaten/kota di Provinsi Jawa Barat, Jawa Tengah, dan Jawa Timur. Pihak yang mengklaim harus dapat membuktikan bahwa akibat dikeluarkannya Peraturan Gubernur tersebut menyebabkan pihak tersebut tidak dapat melaksanakan kewajibannya. Pihak dimaksud harus meneliti apakah pembatasan aktivitas/kegiatan yang diatur dalam PSBB menghambat pelaksanaan kewajiban dan membuktikannya. Tidak hanya itu, Pihak yang mengklaim harus memperhatikan apakah kegiatan usahanya dikecualikan dari ketentuan PSBB tersebut. Sebagai pendukung argumentasi, pihak yang mengajukan klaim force majeure karena pandemi Covid-19 dapat menggunakan Kepres 12 Tahun 2020 sebagai penetapan pemerintah atas status pandemi Covid-19 sebagai bencana nasional. Dalam konteks perpajakan, klaim dapat merujuk misalnya pada Keputusan Dirjen Pajak Nomor Kep-156/PJ/2020 tahun 2020 tentang Kebijakan Perpajakan. Sehubungan dengan Penyebaran Covid2019 yang menetapkan penyebaran Covid-19 dari tanggal 14 Maret 2020 sampai dengan 30 April 2020 sebagai keadaan kahar.

Pada prinsipnya, Pihak yang mengklaim harus dapat membuktikan secara patut bahwa adanya force majeure berdampak pada pemenuhan kewajiban serta dasar hukum yang sesuai dengan konteks hubungan hukum diantara para pihak.

3) Klaim diajukan dengan maksud untuk merubah perjanjian dan bukan mengakhiri perjanjian. Penting untuk dipahami bahwa klaim adanya force majeure tidak serta merta menggugurkan kewajiban pihak tersebut. Ketentuan Pasal 1245 KUHPerdata bahkan hanya berkaitan dengan pembebasan atas kewajiban untuk mengganti rugi. Oleh karena itu, pada saat pengajuan klaim force majeure, pihak tersebut seharusnya telah menyiapkan alternatif perubahan perjanjian, misalnya berupa perubahan tenggat waktu pembayaran kredit/pembiayaan, penyesuaian kuantitas, kualitas barang/layanan, milestone kontrak maupun jadwal pelaksanaan layanan (delivery 
time). Apabila disepakati, perubahan perjanjian tersebut lebih baik dituangkan dalam akta notariil dan menjadi bagian yang tak terpisahkan dari perjanjian awal.

4) Mengutamakan penyelesaian secara musyawarah serta tetap tunduk pada tata cara penyelesaian sengketa yang diatur dalam perjanjian. Dalam melakukan negosiasi perubahan perjanjian, para pihak harus sedapat mungkin mengutamakan penyelesaian secara musyawarah dan menghindari penyelesaian melalui litigasi. Dalam situasi saat ini, penyelesaian sengketa melalui jalur litigasi tidak hanya memerlukan proses yang panjang tetapi juga kompleks. Dapat dibayangkan, berapa banyak potensi perkara wanprestasi akibat pandemi Covid-19 yang akan diselesaikan di pengadilan terlebih ditengah situasi pembatasan jarak/fisik saat ini.

5) Berkonsultasi dengan praktisi atau konsultan hukum mengenai opsi-opsi hukum yang dapat dilakukan. Tentu saja, pelaksanaan perjanjian tidak hanya berkaitan dengan aspek bisnis semata, melainkan juga aspek hukum (legal aspek). Oleh karena itu, penting untuk berkonsultasi dengan praktisi/konsultan hukum yang diyakini dapat memberikan opsi hukum yang sesuai dengan kondisi para pihak.

Dari perdebatan dan akhirnya menjadikan perseruan di antara pelaku usaha dengan kelima langkah tersebut, pemerintah harus memfasilitasi dengan memberikan penjelasan status penyebaran Covid-19 termasuk force majeure serta memberikan jalan keluar dalam hal ini dengan dikeluarkannya Peraturan OJK 11/2020, dan dengan dilakukan assesment sehingga menjadi terang persoalnnya dan jalan kaluarnya (Solusi).

\section{Kesimpulan}

Dari pembahasan diatas, disusunlah suatu kesimpulan sebagai bentuk simpulan dari pembahasan (Conclution) yaitu bahwa sejak suatu perjanjian ditetapkan dan disepakati oleh para pihak, maka perjanjian itu mengikat bagi para pihak (pacta sunt servanda) masingmasing pihak tunduk pada isi perjanjian, namun dalam situasi dan kondisi Penyebaran Virus Corona sangat berpengaruh pada keberadaan/eksistensi perjanjian, dimana debitor tidak mempunyai kemampuan untuk memenuhi kewajibannya (prestasinya) maka secara teknis memberikan keringanan dengan penundaan pembayaran kredit kepada kreditur, dan untuk memutuskan apakah debitur adalah layak menerima keringanan lankhanya adalah dengan mengajukan kepada kreditur maka dengan pengajuan tersebut kreditur melakukan penilaian (self-assesment) terhadap debitur .

\section{Daftar Referensi}

\section{Jurnal}

Aminah. (2020). Pengaruh Pandemi Covid 19 Pada Pelaksanaan Perjanjian. Diponegoro Private Law Review, 7(1), 650-656.

Hetharie, Y. (2019). Perjanjian Nominee sebagai Sarana Penguasaan Hak Milik atas Tanah oleh Warga Negara Asing (WNA) Menurut Kitab Undang-Undang Hukum Perdata. SASI, 25(1), 27-38. https:/ / doi.org/10.47268/ sasi.v25i1.147

Kusumastuti, D. (2014). Kebebasan Berkontrak dalam Kontrak Baku Kredit Perumahan. Jurnal Ilmiah Widya Wacana, 9(1), 34-39.

Muhtarom, M. (2014). Asas-Asas Hukum Perjanjian (Suatu Landasan dalam Pembuatan Kontrak). Jurnal SUHUF, 26(1), 48-56. 
Pesulima, T. L., \& Hetharie, Y. (2020). Perlindungan Hukum Terhadap Keselamatan Kerja Bagi Tenaga Kesehatan Akibat Pandemi Covid-19. SASI, 26(2), 280-285. https:// doi.org/10.47268/sasi.v26i2.307

Buku

Komariah. (2002). Hukum Perdata. Malang: Universitas Muhammadiyah Malang.

Muljadi, K., \& Wijaya, G. (2004). Perikatan Pada Umumnya. Jakarta: Raja Grafindo Persada.

Salim, H., \& Nurbani, E. S. (2014). Perbandingan Hukum Perdata: Comparative Civil Law. Jakarta: Rajawali Pers.

Soemadipradja, R. S. S. (2010). Penjelasan Hukum Tentang Keadaan Memaksa. Jakarta: Nasional Legal Reform Program - Gramedia.

\section{Online/World Wide Web}

Hukum Online.com. (n.d.). Masalah Hukum Penundaan Kontrak Akibat Penyebaran Covid-19. Retrieved May 27, 2020, from https:// www.hukumonline.com/berita/baca/lt5e70df2e855cf/masalah-hukumpenundaan-kontrak-akibat-penyebaran-covid-19

KlikLegal.com. (n.d.). Apakah Covid-19 Otomatis Menjadi Dasar Penerapan Force Majeure? Retrieved May 27, 2020, from https://kliklegal.com/apakah-covid-19-otomatismenjadi-dasar-penerapan-force-majeure

Mahfud MD. (n.d.). Perkembangan Problematika dan Implikasi Force Majeure Akibat Covid-19 Bagi Dunia Bisnis. Webinar.

PHNRI, \& Horwath HTL. (n.d.). Survei Sentimen Pasar Hotel \& Restoran di Indonesia Terhadap Pengaruh Wabah COVID-19. Retrieved May 22, 2020, from https://www.hospitalitynet.org/file/152008806.pdf

Wikipedia. (n.d.-a). Gagal Bayar. Retrieved May 26, 2020, from https://id.wikipedia.org/wiki/Gagal_bayar

Wikipedia. (n.d.-b). Keadaan Kahar. Retrieved May 22, 2020, from https://id.wikipedia.org/wiki/Keadaan_kahar 